\title{
Lapsia pesuveden
} mukana

\section{Huomioita maankäyttö- ja rakennuslain uudistuksesta}

\section{Kari Nykänen}

Käynnissä olevalla maankäyttö- ja rakennuslain kokonaisuudistuksella pyritään vastaamaan muuttuvan toimintaympäristömme tarpeisiin, kuten hiilineutraaliin yhteiskuntaan, luonnon monimuotoisuuden varmistamiseen, rakentamisen laadun parantamiseen ja digitalisaation edistämiseen (Lehtinen, 2020). Lain uudistaminen avaa mahdollisuuden parantaa hyvän ympäristön toteuttamisen edellytyksiä - ainakin teoriassa. Uudistuksessa olisi tietenkin arvokasta tunnistaa ne sääntelyn osa-alueet, jotka jo nykyään ovat toimivia. Laaja-alaisia ja poikkisektoraalisia tavoitteita, kuten hiilineutraaliutta, tuskin saavutetaan yhtä lakia tarkistamalla. Tavoitteiden toteutuminen edellyttää koko sääntely-ympäristön ja -järjestelmien tarkastelua, jotta uudistettava laki tukee, täydentää tai kompensoi muita ohjauskeinoja parhaalla mahdollisella tavalla.

Kaavoituksen ja rakentamisen lupajärjestelmien sujuvoittaminen on ollut pitkään MRL:iin liitetty kehittämistarve (HE 102/2012). Kritiikeissä korostuvat mm. kaavoitusjärjestelmän hierarkkisuus ja hitaus (esim. Hurmeranta, 2013, 13-14). Lausumattomana tavoitteena monella toimijalla lienee, ettei säänneltäisi mitään - tai ainakin mahdollisimman vähän. Julkilausuttuna tavoitteena taas on rakennetun ympäristön laadun varmistaminen, joskin laatu voidaan määritellä toimijasta riippuen varsin laveasti esteettisistä arvoista aina tekniseen toteutettavuuteen ja taloudellisuuteen. Voidaan myös kysyä, ovatko hiilineutraalisuus tai luonnon monimuotoisuuden säilyttäminen sekä elinvoiman edistäminen yhteensovitettavia sääntelyllisiä tavoitteita esimerkiksi kaavahankkeen valintatilanteissa. Uudistuksessa tasapainoillaankin yksityisen ja yleisen edun määräytymisen välillä varsinkin laatu- ja vastuukysymyksissä. Kaavoituksessa suunnittelutavoitteista tulee helposti kiinteistöjen hallintaan 
ja arvoon sekä rakentamisen taloudellisuuteen liittyviä laillisuuskysymyksiä (Mäntysalo \& Nyman, 2001, s. 7, 34).

Kaupunkiseutusuunnitelman laatimisvelvollisuus tai rakentamislupamenettelyn kaksivaiheisuus voi myös haitata sujuvoittamispyrkimyksiä, jos kaikki menettelyvaiheet edellyttävät suunnittelua, vuorovaikutusta, vaikutusten arviointia, päätöksentekoa sekä muutoksenhakumahdollisuutta. Jo nykyisen MRL:n osalta todettiin sujuvoittamisen olevan mahdollista lain soveltamismahdollisuuksia hyödyntämällä sekä toimintatapoja muuttamalla (Ympäristöministeriö, 2014, s. 244). Laatua tulisi siten tavoitella paitsi aineellisen sisällön myös prosessien osalta. Ja ehkä sääntelynkin laadukkuutta tulisi tarkastella jonkin yleisen kriteerin, kuten ennakoitavuuden tai joustavuuden, kautta (ks. Mäattä, 2011, s.25-44). Voidaankin kysyä, onko laadusta käyty sisältöteemojen ja sujuvoittamisen ohella riittävän laajaa ja monipuolista keskustelua? Kaavoituksen joustamattomuuden on todettu osittain olevan seurausta muiden ohjauskeinojen puutteesta (OECD, 2017, s. 9-1).

Eräs merkittävimmistä alueidenkäytön suunnittelujärjestelmän kehittämistavoitteista oli yleis- ja asemakaavan muuttaminen yhdeksi skaalautuvaksi kuntakaavaksi. Tavoitteesta kuitenkin luovuttiin. Yleis- ja asemakaava vastaavat tällä hetkellä mittakaavaltaan, aikajänteeltään ja tarkkuudeltaan varsin erilaisista ohjaustehtävistä. Erilaisten ohjaustehtävien, selvitysten, vaihtoehtojen tai vaikutusten arviointien yhdistäminen samaan kaavaprosessiin ei kuulosta ongelmattomalta. Malli voisi kyllä muuttaa yleispiirteistä suunnittelua yksinkertaisempaan ja strategisempaan suuntaan, mutta vastaavasti kuormittaa useilla sisältökysymyksillä ja ohjaustarpeilla asemakaava- tai rakentamisvaihetta. Samaa kaavahierarkian joustavoittamista tavoitellaan nyt ajatuksella yhdistää yleis- ja asemakaavan muutos samaan kaavapäätökseen. Parhaimmillaan tällä menettelyllä ratkaistaan hankalia maankäytön pattitilanteita - ja pahimmillaan romutetaan pitkän tähtäimen strategisia periaatteita yksittäisen kaavahankkeen toteuttamiseksi, vaikkapa elinvoiman edistämisen nimissä.

Eräs lakimuutoksen tavoitteita on ollut maanomistajan aloiteoikeuden vahvistaminen kaavahankkeissa, vaikka nykyinen kuntalakikin sen jo laajasti mahdollistaa. Jopa lähes puolet kuntien asemakaavoista voi nykyään olla ns. hanke- tai kumppanuuskaavoja, jotka lähtevät yksityisen toimijan aloitteesta. Jos ne toteuttavat kunnan strategisia maankäyttöpoliittisia tavoitteita, kaavahankkeeseen ryhtymiselle ei tällöin liene nykyäänkään estettä. Ilmastotavoitteiden kiristyessä on toisaalta entistä tärkeämpää ohjata yhdyskuntarakennetta hiilineutraalisuutta tukevilla ratkaisuilla. Johdonmukaisesti toteutettu maankäyttöpolitiikka mahdollistaa samalla $\mathrm{mm}$. tasapainoisen maa- ja asuntopolitiikan. Myös kuntatalouden kannalta 
on tärkeää ohjata palveluverkkoa ja infrainvestointeja pitkäjänteisesti sekä oikea-aikaisesti. Jos kunnan on ilman harkintamahdollisuutta edistettävä yksityistä kaavahanketta, resurssit hajautetaan tehottomasti. Kaavoitushankkeet toteutuisivat satunnaisina ja hallitsemattomasti eri puolilla kuntaa - eikä se voi olla kestävän yhteiskunnan kehittämisen kannalta järkevää.

Alueiden ja rakentamisen suunnittelu halutaan saattaa vastaamaan muuttunutta digitaalista toimintaympäristöä, minkä avulla voidaan mm. parantaa työn tehokkuutta, vähentää sen päällekkäisyyttä, yhdistää tietoaineistoja sekä lisätä prosessien avoimuutta ja osallistumista (Ekroos, Katajamäki, Kinnunen, Lehtovuori \& Staffans, 2018, s. 28-32). Keskitetyt kansalliset tietokannat tuottavatkin paikkatietoaineistoa, jota voidaan hyödyntää lähtötietona mm. päästölaskennassa, analyyseissä, vertailuissa ja arvioinneissa. Samalla toimintamalleja voidaan vakiinnuttaa sekä yhtenäistää, jolloin ohjaukselle saadaan systemaattisuutta ja vaikuttavuutta. Järjestely palvelee myös kaava- ja lupajärjestelmiin liittyviä informaatiosisältöä, mikä vastaavasti keventää niiden prosesseja. Kaavaprosessien seurannalle ja vuorovaikutukselle digitaalisuus avaa paljon uusia mahdollisuuksia.

Haasteeksi noussee tiedon kerääminen, hallinnointi sekä sen hyödyntäminen. Keskitettyjen tietokantojen tai -mallien ei tulisi tuoda kunnille, yrityksille tai yksityisille ihmisille kohtuuttomia kustannuksia tai työvelvoitteita. Aluemallinnusten ja 3D-kaavojen avulla toteutetussa kaavaprosessissa osalliselle tulee pystyä edelleenkin välittämään tieto suunnitelmavaihtoehdoista, osallistamisen muodoista sekä kaavaratkaisun tuottamasta ympäristön muutoksesta, vaikkei tämä ehkä enää olisikaan kaavavaiheen mukainen paperikopio vaan muutos sähköisessä tietojärjestelmässä. Objektiivisen ympäristötiedon ja subjektiivisen osallistiedon yhdistäminen tietoaineistoksi tarkoittaa edelleenkin arvovalintoja kaava- tai luparatkaisua haettaessa. Sähköiset tietojärjestelmät edellyttävät kuntalaisilta ja päättäjiltä valmiuksia hyödyntää niitä ja ymmärtää niiden sisältöjä sekä prosesseja. Muuten täytyy ylläpitää kahta päällekkäistä järjestelmää, eivätkä prosessit silloin kevene. Avoimiin paikkatieto- ja seurantajärjestelmiin voi liittyä myös tiedon kaupalliseen hyödyntämiseen tai yksityisyyden suojaan liittyviä tekijöitä, joita on hyvä pohtia ennakkoon.

Tietomalli sinällään ei vielä vaadi suunnittelutaitoa, jota hyvän ympäristön tai rakennuksen luominen väistämättä edellyttää. Tämä voi johtaa suunnitelmien laadun heikentymiseen, jos tietomallista tulee rakennus- tai kaavoitushankkeen kynnyskysymys. Tietojärjestelmien ja mallinnusohjelmien edellyttäminen ei saa johtaa tiettyjen toimijoiden tai järjestelmätoimittajien monopoliasemaan, mikä nostaa suunnittelun kustannuksia ja pahimmillaan vääristää kilpailua. Jää nähtäväksi, pystyykö tietomalli kuvaamaan ympäristön muutosta osallisille abstraktia 2D-kaavakarttaa paremmin. Digitaalisuuden 
vaatimukset lainsäädäntöön kirjattuna eivät luonnollisesti saisi estää jo toimivia käytäntöjä tai luovia ratkaisuja jatkossakaan. Digitaalisuus on hyvä renki, mutta huono isäntä.

Lainvalmistelua on lähestytty osa-alueittain, mitä voi pitää laajan kokonaisuuden haltuun ottamiseksi tarkoituksenmukaisena. Haasteena onkin siten ehkä ollut kokonaisuuden hahmottaminen, sillä valmistelun osa-alueet ovat voineet edetä toisistaan riippumatta, keskittyä yksityiskohtiin tai sisältöä ei ole tuotu kommentoitavaksi. Säädöslähtöinen tarkastelu johtanee uudistuksessa erilaisiin ratkaisumalleihin kuin ongelmalähtöinen tarkastelu (ks. Mäattä, 2011, s. .11). Ensimmäinen tuottanee tarkennuksia ja muutoksia nykyisen lainsäädännön periaatteiden pohjalta. Jälkimmäinen taas mahdollistanee helpommin sopivien ja ehkäpä uusien, ohjaustyökalujen ja -muotojen kehittelemistä lainsäädännön sisälle.

Kritiikkiä uudistuksesta on helppoa huudella takavasemmalta, tuntematta tarkemmin kokonaisuuden ohjelmointia, tutkittuja vaihtoehtoja, eri vaiheita sekä niiden yhteydessä käytyä vuorovaikutusta. Ja jostainhan lakipykälienkin luonnostelu on aloitettava. Osa muutoskritiikistä johtunee MRL:a työkseen soveltavien toimijoiden vastustuksesta, sillä on helpompi puolustaa tuttua järjestelmää. Epäilemättä lain soveltajankin asenteissa ja ajattelutavoissa on tarkistamisen varaa, koska näin uudet sääntelyavaukset ja -innovaatiot saattavat jäädä tutkimatta ja toteutumatta. Toisaalta juuri soveltajilta kannattaisi kysyä keinoja sääntelyn sujuvoittamiseen, sillä kukapa omasta työstään ei haluaisi karsia turhia vaiheita tai sisältöjä pois. MRL:n uudistukseen on sisälletty paljon vuorovaikutusta. Palautteen antamista vaivaa osin valmistelun sirpalemaisuus, missä yksittäiset säännökset osana kokonaisuutta jäävät helposti hahmottumatta. Muutoskritiikin taustalla lienee myös yleisemmin pelko ympäristösääntelyn tason heikentymisestä, uusien menettelyjen epäselvyydestä tai ohjausresurssien puuttumisesta. Aiheellinen huoli sekin, sillä ympäristöön ja sen käyttöön liittyvän sääntelyn muutoksessa suurin häviäjä on pahimmillaan juuri ympäristö.

Kirjoittaja on arkkitehti SAFA, TkT, Oulun kaupungin asemakaavapäällikkö sekä SAFAn MRL-työryhmän jäsen.

KIRJALLISUUS

Ekroos, A., Katajamäki, H., Kinnunen, H., Lehtovuori, P. \& Staffans, A. (2018). Maankäytön ja rakentamisen ohjauksen uudistaminen. Ympäristöministeriön raportteja 7/2018, Helsinki: ympäristöministeriö. http://urn.fi/URN:ISBN:978-952-11-4784-5

HE 102/2012. Hallituksen esitys Eduskunnalle laiksi maankäyttö- ja rakennuslain muuttamiseksi.

Hurmeranta, M. (2013). Kaavoihin kangistuneet. Tusina ratkaisua kaavoituksen hitauteen ja tehottomuuteen. EVA Elinkeinoelämän valtuuskunta. Helsinki: Taloustieto. https://www.eva.fi/ wp-content/uploads/2013/o5/Kaavoihin-kangistuneet.pdf 
Lehtinen, T. (2020). Kuulumiset maankäyttö-ja rakennuslain uudistuksesta. Blogikirjoitus 5.10.2020, www. mrluudistus.fi

Mäntysalo, R. \& Nyman, K. (2001). Kaavoitus - suunnittelua? Suunnittelun patologioita maankäyttö- ja rakennuslain sovelluksissa. Arkkitehtuurin osasto, julkaisu A30, Oulu: Oulun yliopisto. http://jultika. oulu.fi/files/isbn9514265629.pdf

Määttä, K. (2011). Laadukas lainsäädäntö osana valtiontaloudellista päätöksentekoa. Valtiontalouden tarkastusviraston tutkimuksia ja selvityksiä. Helsinki: Valtiontalouden tarkastusvirasto. https://www. vtv.fi/app/uploads/2018/og/10114611/laadukas-lainsaadanto-2011.pdf

OECD. (2017). The Governance of Land Use in OECD Countries. Policy Analysis and Recommendations. Paris: OECD Publishing. https://doi.org/10.1787/97892642686o9-en

Ympäristöministeriö. (2014). Arviointi maankäyttö- ja rakennuslain toimivuudesta 2013. Suomen Ympäristö 2014(1). Helsinki: Ympäristöministeriö 